\title{
СУТНІСТЬ АДМІНІСТРАТИВНО-ПРАВОВИХ СПОРІВ: ТЕОРЕТИКО-ПРАВОВИЙ АСПЕКТ
}

Калантай М. В.

В статmі розкрито сутність та досліджено природу виникнення адміністративно-правового спору, охарактеризовано суб'єктів спору та його предмет. Визначено складові структури адміністративно-правового спору. Встановлено основні способи вирішення адміністративно-правового спору, які доповнюють один одного: адміністративний та судовий. Також звертається увага на основні завдання адміністративної юстиції.

Ключові слова: адміністративно-правовий спір, публічно-правові відносини, публічно-правовий спір.

В статье раскрыта сущность и исследована природа возникновения административно-правового спора, охарактеризованы субъекты спора и его предмет. Определень элементы структуры административно-правового спора. Установлены основные способы решения административно-правового спора, которые дополняют друг друга: административный и судебный. Также в статье обращается внимание на основные задачи административной юстиции.

Ключевые слова: административно-правовой спор, публично-правовые отношения, публично-правовой спор.

The aim of this article is issues of legal conflicts, in particular administrative-legal disputes, which are the synthesis of problems of conflictology with the provisions of legal science. It is established that the feature of a legal dispute is that it is associated with the execution or violation of certain rules of law.

On the basis of analysis of scientific works and norms of legislation the essence of the dispute is revealed and the nature of the emergence of an administrative-legal dispute is investigated. The components of the structure of the administrative-legal dispute, namely the subject, the subjects, as well as the process of confrontation of the parties in the dispute, are determined.

The main ways of resolving the administrative-legal dispute, which complement each other: administrative and judicial, are established.

The author notes that the right of a citizen to appeal for a court provided for by the Constitution of Ukraine and the current legislation was an important factor in strengthening the guarantees of citizens' rights in the sphere of functioning of the executive power. In the conditions of separation of powers, the role of the judiciary in protecting the rights and legitimate interests of citizens must be significantly expanded. This is due to the fact that the judicial procedure for reviewing administrative disputes has several advantages compared with the procedure for resolving the dispute by executive authorities. The experience of European countries also testifies the need to expand the range of administrative-legal disputes, which relates to court jurisdiction.

The article analyzes the rules of consideration administrative-legal disputes.

Attention is drawn to the importance of the problem of delimitation of judicial jurisdictions in order to ensure the rights, freedoms and legitimate interests of citizens. The main task of administrative justice is determined.

Key words: administrative legal dispute, public-law relations, public legal dispute.

Калантай М. В., 2019
Постановка проблеми та її актуальність. Питання юридичних конфліктів, до яких можемо віднести адміністративно-правові спори, викликають особливий інтерес для науковців, оскільки являють собою синтез проблем конфліктології з положеннями юридичної науки. Взагалі термін «конфлікт» у перекладі з латиниці означає зіткнення протилежних інтересів, прагнень, спір, що може привести до ускладнень. Багато соціальних конфліктів лежать у площині правових відносин, їх виникнення пов'язане із юридичними фактами, а вирішення - із застосуванням правових інструментів та методів врегулювання конфліктів, включаючи судові процедури. Особливістю юридичного спору $\epsilon$ те, що він пов'язаний з реалізацією або порушенням тих чи інших норм права.

За обставин, коли одна зі сторін адміністративних правовідносин вважає, що ії суб'єктивні права чи законні інтереси порушуються або обмежуються діями другої сторони, яка цього не визнає, виникає адміністративно-правовий спір.

Аналіз останніх досліджень і публікацій. Проблематиці адміністративно-правового спору та взагалі дослідженню предмета адміністративного судочинства присвятили свої праці такі науковці, як В.Б. Авер'янов, Ю.П. Битяк, І.Б. Коліушко, Т.О. Коломоєць, В.К. Колпаков, А.Т. Комзюк, Є.Б. Лупарєв, О.М. Пасенюк, Н.Б. Писаренко, О.П. Рябченко, В.А. Сьоміна, Н.Ю. Хаманева та інші. Проте питання зазначеної проблематики потребують подальшого дослідження.

Метою статті $\epsilon$ визначення сутності та природи виникнення адміністративно-правового спору.

Виклад основного матеріалу. Юридичний конфлікт у царині адміністративного права має свою специфіку, обумовлену характером відносин у сфері функціонування виконавчої влади, адже ці відносини мають публічно-правовий характер. Якщо вони набувають форму спірних правовідносин, то виникає такий різновид юридичного конфлікту як адміністративно-правовий спір [1, с. 29].

Суб'єкти зазначених правовідносин різноманітні, у наслідок чого конфлікти можуть виникати між самими органами виконавчої влади, між органом виконавчої влади та юридичною особою приватного права, громадянами, органами місцевого самоврядування i т.д. Перелік справ, на які поширюється юрисдикція адміністративних судів визначено у ст. 19 Кодексу адміністративного судочинства України (далі - КАС України) [2].

Різноманіття й складність керуючої та керованої підсистем суспільства часто призводять до різного, часом діаметрально протилежного сприйняття людьми (а саме через їх сприйняття реалізується та чи інша адміністративно-правова норма) цілей, завдань державної управлінської діяльності, що може привести до виникнення адміністративно-правового спору [3, с. 3]. Юридична природа цього роду правових спорів ще не 
$\epsilon$ досить дослідженою. Разом з тим слід зазначити, що ці спори мають специфічний характер і ознаки.

Адміністративно-правові спори виникають у сфері державного управління в процесі здійснення органами виконавчої влади управлінських функцій. Для цієї категорії спорів характерне особливе становище їхніх суб'єктів - учасників спірних правовідносин. Обов' язковим учасником адміністративно-правового спору $\epsilon$ наділений владними повноваженнями орган виконавчої влади, місцевого самоврядування, їхні структурні підрозділи, посадові особи, наділені державно-владними повноваженнями. Адміністративно-правовий спір має особливий предмет, пов'язаний з широким діапазоном напрямків діяльності управлінського характеру. Характерною ознакою спорів даної категорії $\epsilon$ особливий порядок їх вирішення, а також специфічні засоби і способи захисту. Це обумовлює необхідність спеціального адміністративно-правового регулювання процедури розгляду адміністративно-правових спорів. Дані спори вирішуються як в адміністративному, так і в судовому порядку, тобто за певною процесуальною формою. У першому випадку це врегульовано Законом України «Про звернення громадян» [4], а в другому - КАС України [2]. Таким чином, спірні адміністративні правовідносини несуть у собі елементи як матеріально-правового, так і процесуального характеру, притаманні саме для цієї категорії спорів.

Особливий інтерес з позиції юридичного конфлікту становить взаємозв'язок «громадянин» - «орган виконавчої влади», коли ці відносини набувають форму адміністративно-правового спору. У сфері адміністративного права подібні ситуації виникають, приміром, у разі порушення органом виконавчої влади прав і свобод громадян. Характер цього спору обумовлений не стільки через участь у ньому адміністративного органу (як обов'язкової сторони), скільки природою відносин між цим органом і зацікавленою особою. Адже адміністративні органи можуть перебувати з громадянами або організаціями в правовідносинах різного змісту: адміністративних, цивільних, господарських, трудових тощо. 3 цього випливає, що адміністративні дії призводять у ряді випадків не тільки до адміністративних, а й інших (наприклад, цивільно-правових) наслідків. У такому разі спір втрачає власне адміністративно-правовий характер.

В юридичній науці поширеною $\epsilon$ точка зору, згідно з якою спір відносять до категорії адміністративних спорів, якщо юридичне питання, що складає зміст спору, тобто правовідносини між сторонами, $є$ питанням адміністративного права [5, с. 6]. У зв'язку із цим можемо погодитись із позицією Є.Б. Лупарєва, що розглядати матеріально-правові відносини між сторонами слід як однин з елементів змісту спору [3, с. 26].

Водночас аналіз приписів чинного законодавства дає змогу стверджувати, що суперечки з владарюючими суб'єктами можуть виникати не тільки з адміністративно-правових відносин, а і з тих, що регламентуються іншими, приміром, комплексними чи спеціальними галузями права, які $є$ похідними або щільно пов'язаними з правом адміністративним. Так, до правових спорів може призвести діяльність суб'єкта владних повноважень, унормована митним, фінансовим, податковим, земельним чи екологічним правом.

Отже, адміністративно-правовий спір у вузькому значенні можна сприймати як конфлікт, що виник з адміністративно-правових відносин, а в широкому як пов'язаний із правовідносинами будь-якої галузевої належності, однак які зумовлені управлінською діяльністю представників влади [6, с. 10-11].

Як правило, адміністративно-правові спори виникають з ініціативи керованої сторони, що відчуває на собі вплив з боку керуючої (орган виконавчої влади, посадова особа) і вважає цей вплив, приміром, видання акта управління, неправомірним, таким, що порушує їі права та інтереси. Кожна зі сторін такого спору, вочевидь, зацікавлена у вирішенні проблеми на свою користь. Це i $\epsilon$ те протиріччя, через яке і заради розв'язання якого суб'єкти вступають у протистояння і на підставі якого виникає адміністративно-правовий спір [5, с. 8].

Таким чином, у структурі адміністративно-правового спору можна виокремити не тільки суб'єктів і предмет конфлікту, а також процес протистояння сторін у споpi, за допомогою якого реалізуються цілі та завдання спору. Цей процес може втілюватися у двох основних способах вирішення адміністративно-правових спорів, які знаходяться в тісному взаємозв' язку: адміністративному та судовому.

Значна частина адміністративно-правових спорів вирішується в позасудовому порядку. Особа, що не погоджується з рішенням іншої сторони адміністративно-правових відносин і звертається зі скаргою до відповідного вищого органу (посадової особи). У цьому випадку оцінка правомірності оскаржуваних дій (рішень) $є$ прерогативою уповноваженого на те органу (посадової особи). Як було зазначено раніше, цей порядок вирішення адміністративно-правових спорів врегульовано Законом України «Про звернення громадян».

Сьогодні важливу роль у вирішенні адміністративно-правових спорів грають судові органи. Передбачене Конституцією України а також чинним законодавством право громадянина звертатися за захистом до суду стало вагомим фактором зміцнення гарантій прав громадян у сфері функціонування виконавчої влади. В умовах поділу влади повинна значно зростати роль саме судової влади у захисті прав і законних інтересів громадян. Це пов'язано з тим, що судовий порядок розгляду адміністративно-правових спорів має ряд переваг у порівнянні з порядком вирішення спору органами виконавчої влади. Так, громадянин і державний орган (посадова особа) беруть участь у справі в якості сторін, що мають рівні процесуальні права і обов'язки, що забезпечує позицію громадянина як повноправної сторони спору.

3 позиції правової доктрини, що панує в більшості європейських країн, забезпечення законності й поваги прав громадян вимагають розширення кола справ у спорах між громадянином і адміністрацією, що відносяться до судової юрисдикції.

Варто зазначити, що вказані способи вирішення адміністративно-правових спорів не виключають один одного, а органи виконавчої влади та судові органи, перебуваючи в різноманітних відносинах між собою, доповнюють один одного. У цьому зв'язку адміністративний і судовий порядок вирішення спорів $\epsilon$ елементами єдиної системи забезпечення законності охорони прав громадян у демократичній правовій державі.

Адміністративно-правові спори розглядаються за правилами адміністративного судочинства. Так, відповідно до п. 1 ч. 1 ст. 4 КАС України адміністративна справа - це переданий на вирішення адміністративного 
суду публічно-правовий спір. Згідно з п. 2 ч. 1 ст. 4 КАС України публічно-правовий спір - це спір, в якому хоча б одна сторона здійснює публічно-владні управлінські функції, у тому числі на виконання делегованих повноважень, і спір виник у зв'язку із виконанням або невиконанням такою стороною зазначених функцій; або хоча $б$ одна сторона надає адміністративні послуги на підставі законодавства, яке уповноважує або зобов'язує надавати такі послуги виключно суб'єкта владних повноважень, i спір виник у зв'язку із наданням або ненаданням такою стороною зазначених послуг; або хоча б одна сторона $є$ суб'єктом виборчого процесу або процесу референдуму і спір виник у зв'язку із порушенням їі прав у такому процесі з боку суб'єкта владних повноважень або іншої особи.

На підставі аналізу норм КАС України К. О. Тимошенко висловила думку, про те, що предметом юрисдикції адміністративних судів України $\epsilon$ всі публічно-правові спори, за винятком тих, які, відповідно до Конституції України та законів України, підлягають вирішенню в порядку іншого судового провадження. [7, с. 13].

У своїх дослідженнях науковці неодноразово наголошували на важливості проблеми розмежування судових юрисдикцій для гарантування прав, свобод і законних інтересів громадян, та вказували на нечітке розмежування предмета конституційної юрисдикції та юрисдикції інших судів, що стосується спорів у публічно-правових відносинах [8, с. 175]. Принагідно зауважимо, що поява проблеми розмежування судових юрисдикцій прогнозувалася ще у 2005-2006 роках, коли адміністративні і господарські суди в межах підвідомчості почали розглядати справи адміністративної юрисдикції. Підготовлені вищими судовими органами роз'яснення з цього питання, на жаль, не містили вичерпних рекомендацій, особливо якщо виникав спір щодо господарської діяльності за участі органу виконавчої влади, органу місцевого самоврядування.

Можемо погодитись із думкою проф. О.П. Рябченко, що головна відмінність між конституційними й адміністративними правовідносинами полягає в їхньому змісті. Хоча обидва види правовідносин виникають у сфері діяльності органів державної влади, місцевого самоврядування і пов'язані з організацією їхньої діяльності, проте конституційні правовідносини мають державно-політичний зміст, а адміністративні - організаційно-регулятивний [8, с. 176].

Основне завдання адміністративної юстиції - утвердження верховенства права над адміністративним свавіллям, захист прав і законних інтересів громадян від неправомірних дій і рішень органів виконавчої влади та, зрештою, забезпечення законності у сфері публічного управління. Відповідно, адміністративну юстицію можна розглядати як спеціальну гілку правосуддя, що забезпечує судовий контроль за публічною владою в ході вирішення спорів публічно-правового характеру за допомогою особливих процесуальних правил. Спе- ціалізація судів насамперед пов'язана з необхідністю досконалого вивчення й правильного застосування суддями масиву законодавства, що використовується при розгляді певної категорії справ у сфері управління. Внаслідок складності названої категорії справ їх розгляд і правильне вирішення вимагають високого професіоналізму суддівського корпусу, спеціального навчання суддів.

Висновки. Отже, спір вважається адміністративним, якщо юридичне питання, що становить його зміст (тобто матеріально-правове відношення, яке пов'язує сторони), є питанням адміністративного права. Предметом судового розгляду у справах, що виникають із публічно-правових відносин, може бути широке коло відносин, які регулюються нормами різних галузей права. Структуру адміністративно-правового спору складають не тільки суб'єкти і предмет конфлікту, а також процес протистояння сторін у спорі, за допомогою якого сторони реалізують свої цілі.

Оскільки у світі немає ідеальної держави, в якої б не виникали певні конфліктні ситуації між громадянами та владними структурами, то вивчення проблем спірних правовідносин, причин, умов їх виникнення, а також способів вирішення спорів у сфері державного управління вбачається надзвичайно актуальним.

\section{Література}

1. Хаманева Н.Ю. Теоретические проблемы административно-правового спора. Государство и право. 1998. № 12. С. 29-36.

2. Кодекс адміністративного судочинства України від 6 липня 2005 р. № 2747-IV. Відомості Верховної Ради України. 2005. № 35-37. Ст. 446.

3. Лупарев Е.Б. Общая теория административно-правового спора : монография. Воронеж : ВГУ, 2003. 248 с.

4. Про звернення громадян : Закон України від 2 жовтня 1996 р. № 393/96-BP. URL: https:// zakon.rada.gov.ua/laws/show/393/96-\%D0\%B2\%D1\%80 (дата звернення: 11.04.2019).

5. Хаманева Н.Ю. Административно-правовые споры: проблемы и способы их разрешения. Государство и право. 2006. № 11. С. 5-13.

6. Писаренко Н.Б., Сьоміна В.А. Адміністративно-правові спори (удосконалення порядку вирішення) : монографія. Харків, 2011, 136 с.

7. Тимошенко К. О. Публічно-правовий спір як предмет юрисдикції адміністративних судів : автореф. дис. ... канд. юрид. наук : спец. 12.00.07. Київ, 2013. 20 с.

8. Рябченко О.П. Категорія «публічно-правовий спір»: розмежування конституційної та адміністративної юрисдикцій. Вісник Конституційного Суду України. 2011. № 4-5. С. 174-178.

Калантай М. В., здобувачка кафедри адміністративного права Національного юридичного університету імені Ярослава Мудрого 